\title{
Loktanella atrilutea sp. nov., isolated from seawater in Japan
}

\author{
Shoichi Hosoya and Akira Yokota
}

Correspondence

Shoichi Hosoya

shouichi.hosoya@mbio.jp
Institute of Molecular and Cellular Biosciences, The University of Tokyo, Yayoi 1-1-1, Bunkyo-ku, Tokyo 113-0032, Japan

\begin{abstract}
A Gram-negative, rod-shaped bacterium, $I G 8^{\top}$, was isolated from seawater off the Sanriku coast, Japan. Phylogenetic analysis based on $16 \mathrm{~S}$ rRNA gene sequences showed that strain IG8 ${ }^{\top}$ represented a separate lineage within the genus Loktanella; the highest 16S rRNA gene sequence similarity values were found with the type strains of Loktanella salsilacus (98.6\%) and Loktanella fryxellensis (98.4\%). DNA-DNA hybridization values between strain IG8 $^{\top}$ and the type strains of $L$. salsilacus (27.9-36.1\%) and L. fryxellensis (11.3-31.0\%) were clearly below $70 \%$, the generally accepted limit for species delineation. The DNA G + C content of strain IG8 ${ }^{\top}$ was $66.3 \mathrm{~mol} \%$. On the basis of DNA-DNA hybridization, some biochemical characteristics and 16S rRNA gene sequence comparison, it is proposed that the isolate represents a novel species, Loktanella atrilutea sp. nov. The type strain is $1 G 8^{\top}\left(=I A M 15450^{\top}=\mathrm{NCIMB} 14280^{\top}\right)$.
\end{abstract}

The genus Loktanella was first described by Van Trappen et al. (2004) and contained three species, Loktanella salsilacus, Loktanella fryxellensis and Loktanella vestfoldensis. Recently, four more species, Loktanella hongkongensis (Lau et al., 2004), Loktanella agnita, Loktanella rosea (Ivanova et al., 2005) and Loktanella koreensis (Weon et al., 2006), have been reported.

In this study, the taxonomic position of strain IG $8^{\mathrm{T}}$, isolated from seawater off Masaki on the Sanriku coast, Iwate Prefecture, Japan, was determined. The seawater sample $(0.05 \mathrm{ml})$ was spread onto a plate containing modified gelatin agar $[0.75 \times$ artificial seawater (ASW; $1 \times$ ASW consists of $3 \% \mathrm{NaCl}, 0.07 \% \mathrm{KCl}, 1.08 \% \mathrm{MgCl}_{2} .6 \mathrm{H}_{2} \mathrm{O}$, $0.54 \% \mathrm{MgSO}_{4} .7 \mathrm{H}_{2} \mathrm{O}$ and $\left.0.1 \% \mathrm{CaCl}_{2} .2 \mathrm{H}_{2} \mathrm{O}\right), 0.4 \%$ gelatin, $0.025 \%$ peptone, $0.025 \%$ yeast extract, $0.001 \%$ $\mathrm{FeSO}_{4} \cdot 7 \mathrm{H}_{2} \mathrm{O}, \quad 0.001 \% \mathrm{Na}_{2} \mathrm{HPO}_{4}$ and $1 \%$ agar] and incubated at $25{ }^{\circ} \mathrm{C}$ for a week. Strain IG8 ${ }^{\mathrm{T}}$ was purified and maintained at $25{ }^{\circ} \mathrm{C}$ on marine agar 2216 (MA; Difco).

$16 \mathrm{~S}$ rRNA gene sequences were obtained by direct sequencing of PCR-amplified DNA as described by Hosoya et al. (2006). The most closely related sequences were found using the BLAST program from the GenBank database (Altschul et al., 1990). Multiple alignments were performed by using the CLUSTAL_X program (version 1.83; Thompson et al., 1997). Nucleotide substitution rates ( $K_{\text {nuc }}$; Kimura, 1980) were determined and a phylogenetic tree was constructed using the neighbour-joining method (Saitou \& Nei, 1987). Alignment gaps and unidentified

Abbreviation: ASW, artificial seawater.

The GenBank/EMBL/DDBJ accession number for the 16S rRNA gene sequence of strain $I G 8^{\top}$ is $A B 246747$. base positions were not taken into consideration in the calculation. Bootstrap analysis was based on 1000 trials. The results of the phylogenetic analysis based on $16 \mathrm{~S}$ rRNA gene sequences showed that strain $\mathrm{IG}^{\mathrm{T}}$ belonged to the genus Loktanella (Fig. 1). The highest 16S rRNA gene sequence similarity values were found with the type strains of L. salsilacus (98.6\%) and L. fryxellensis (98.4\%); similarity values with the type strains of L. vestfoldensis, L. hongkongensis, L. agnita, L. rosea and L. koreensis were 95.5, 94.6, 94.6, 94.5 and $93.9 \%$, respectively. L. salsilacus LMG $21507^{\mathrm{T}}$ and L. fryxellensis LMG $22007^{\mathrm{T}}$, which are the closest relatives of strain $\mathrm{IG}^{\mathrm{T}}$, were obtained from the BCCM/LMG Bacteria Collection (Belgium). Genomic DNA was extracted by the method of Saito \& Miura (1963). For analysis of genetic relatedness, DNA-DNA hybridization was carried out at $49{ }^{\circ} \mathrm{C}$ for $4 \mathrm{~h}$ and measured fluorometrically using the method of Ezaki et al. (1989). Strain IG8 ${ }^{\mathrm{T}}$ showed relatively low DNA-DNA relatedness values to $L$. salsilacus LMG $21507^{\mathrm{T}}(27.9-$ $36.1 \%)$ and L. fryxellensis LMG $22007^{\mathrm{T}}$ (11.3-31.0\%). These values are significantly lower than that accepted as the phylogenetic definition of a species (Wayne et al., 1987). The DNA G $+C$ content was determined by HPLC according to the method of Mesbah et al. (1989). The DNA $\mathrm{G}+\mathrm{C}$ content of strain $\mathrm{IG}^{\mathrm{T}}$ was $66.3 \mathrm{~mol} \%$; the DNA $\mathrm{G}+\mathrm{C}$ contents of the reference strains $L$. salsilacus and L. fryxellensis are given in Table 1 .

The following phenotypic characteristics were determined. Cell morphology was observed by using transmission electron microscopy (TEM) after negative staining with phosphotungstic acid. Gram staining was performed using the Hucker staining method as described by Smibert \& Krieg (1994). Spore staining was performed using the 


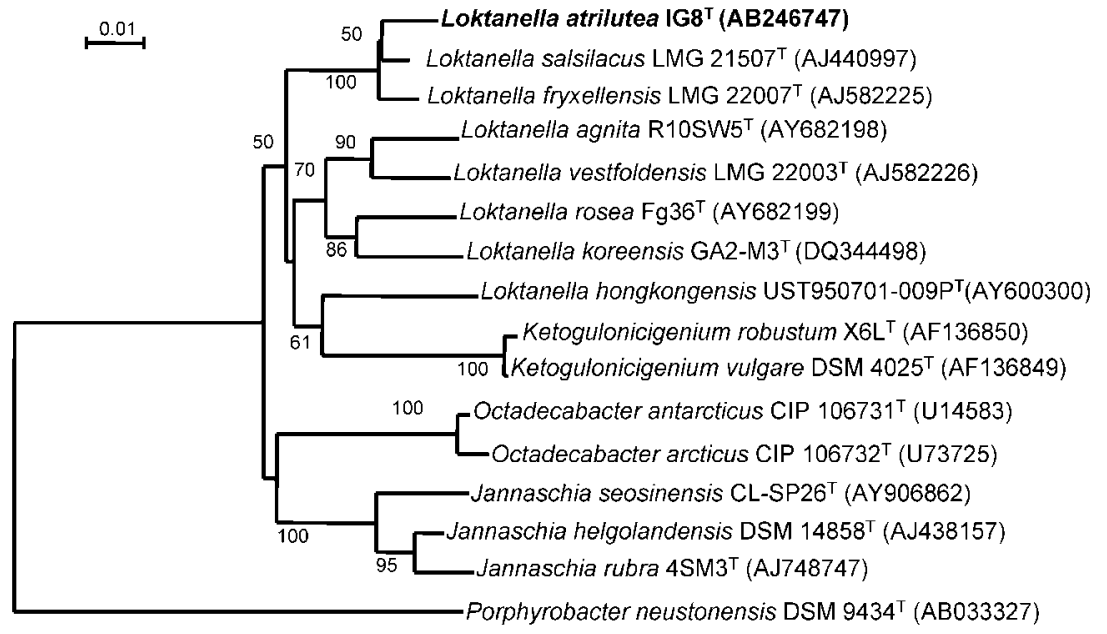

Fig. 1. Neighbour-joining phylogenetic tree of Loktanella atrilutea and other related genera of the class Alphaproteobacteria based on $16 S$ rRNA gene sequence analysis. Bootstrap values greater than $50 \%$ are given at branch points. Bar, 0.01 nucleotide substitutions per site.
Schaeffer \& Fulton staining method as described by Barrow \& Feltham (1993). Salt tolerance was tested on R2A agar (Difco) supplemented with $0-10 \% \mathrm{NaCl}$. In addition, the growth of colonies on nutrient agar (NA; Difco) and trypticase soy agar (TSA; BBL) was tested. Growth at different temperatures $\left(8-37{ }^{\circ} \mathrm{C}\right.$ ) and $\mathrm{pH}$ values (range $\mathrm{pH}$ 5.0-9.0), cytochrome oxidase and catalase activities, and degradation of alginate were determined by previously described methods (Hosoya et al., 2006). Hydrolysis of DNA was determined on DNA agar (Nissui) supplemented with $0.5 \times$ ASW. Degradation of casein was tested on NA supplemented with $0.5 \times$ ASW by the method of Smibert \& Krieg (1994). Degradation of starch was tested on SP5 medium containing $0.2 \%$ soluble starch by the method of Smibert \& Krieg (1994). Hydrolysis of Tweens (20, 40, 60 and 80$)$ was tested on modified Tween 80 medium [containing $0.1 \%$ peptone, $0.5 \times$ ASW, $1 \%(\mathrm{v} / \mathrm{v})$ Tweens and $2 \%$ agar] according to the method of Barrow \& Feltham (1993). Degradation of L-tyrosine was tested on

Table 1. Differential characteristics of strain $I G 8^{\top}$, L. salsilacus LMG $21507^{\top}$ and L. fryxellensis LMG $22007^{\top}$

Strains: 1, L. atrilutea sp. nov. IG8 ${ }^{\mathrm{T}} ; 2$, L. salsilacus $\mathrm{LMG} 21507^{\mathrm{T}} ; 3, \mathrm{~L}$. fryxellensis $\mathrm{LMG} 22007^{\mathrm{T}}$.

\begin{tabular}{|lccc|}
\hline Characteristic & $\mathbf{1}$ & $\mathbf{2}$ & $\mathbf{3}$ \\
\hline$\beta$-Galactosidase & - & + & - \\
$\alpha$-Glucosidase & + & + & - \\
Acid production from: & & & \\
$\quad$ Arabinose & + & + & - \\
Cellobiose & + & + & - \\
Glycerol & - & + & - \\
Inositol & - & + & + \\
Rhamnose & + & - & + \\
Sorbitol & + & - & + \\
Trehalose & - & + & + \\
DNA G+C content $(\mathrm{mol} \%)$ & 66.3 & 62.2 & 67.4 \\
& & & \\
\hline
\end{tabular}

NA containing $0.5 \%$ L-tyrosine, supplemented with $0.5 \times$ ASW using the method of Barrow \& Feltham (1993). Acid production from carbon sources was assessed using Leifson modified O/F medium incubated for 10 days (Smibert \& Krieg, 1994). Tests with the commercial API ZYM and API $20 \mathrm{E}$ systems (bioMérieux) were generally performed according to the manufacturer's instructions. The API ZYM tests were read after $4 \mathrm{~h}$ incubation at $37{ }^{\circ} \mathrm{C}$ and API $20 \mathrm{E}$ tests were read after $48 \mathrm{~h}$ at $25^{\circ} \mathrm{C}$. Cells for inoculation onto the API test strips were suspended in $0.5 \times$ ASW. For analysis of cellular fatty acids, cells were grown for $48 \mathrm{~h}$ at $25{ }^{\circ} \mathrm{C}$ on MA and were analysed using the GC-based Microbial Identification system (MIDI).

Strain IG8 ${ }^{\mathrm{T}}$ was a Gram-negative, aerobic, rod-shaped, non-sporulating bacterium. Cells were approximately 1.8$2.0 \mu \mathrm{m}$ long by $0.5-1.0 \mu \mathrm{m}$ wide and motile by means of a subpolar flagellum (Fig. 2). The isolate formed beigecoloured colonies that turned dark orange in the stationary phase. Phenotypic characteristics are given in Table 1 and in the species description. Phenotypically, strain IG8 ${ }^{\mathrm{T}}, L$. salsilacus LMG $21507^{\mathrm{T}}$ and L. fryxellensis LMG $22007^{\mathrm{T}}$ differed from each other in their $\beta$-galactosidase and

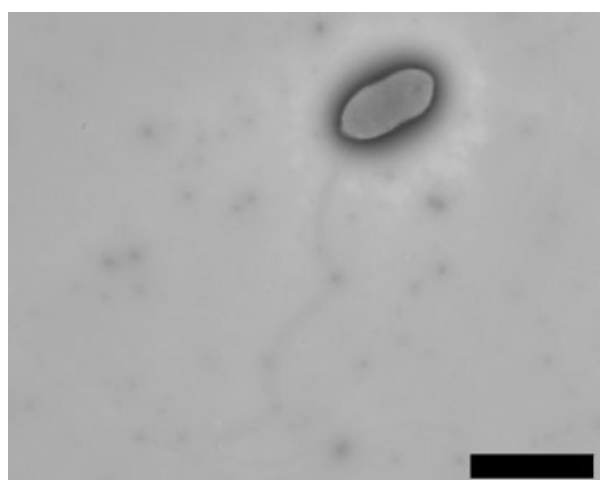

Fig. 2. TEM of a negatively stained cell of strain $I G 8^{\top}$. Bar, $2 \mu \mathrm{m}$. 
$\alpha$-glucosidase activities and in their ability to produce acid from arabinose, cellobiose, glycerol, inositol, rhamnose, sorbitol and trehalose. The major cellular fatty acid of strain IG8 ${ }^{\mathrm{T}}$, L. salsilacus LMG $21507^{\mathrm{T}}$ and L. fryxellensis LMG $22007^{\mathrm{T}}$ was $18: 1 \omega 7 c$, however, strain $\mathrm{IG}^{\mathrm{T}}$ also contained the fatty acid 11 -methyl $18: 1 \omega 7 c$, which was not detected in L. salsilacus or L. fryxellensis (Table 2).

On the basis of DNA-DNA hybridization, phylogenetic analysis and phenotypic characteristics, strain $\mathrm{IG}^{\mathrm{T}}$ is proposed as a novel species of the genus Loktanella, Loktanella atrilutea sp. nov.

\section{Description of Loktanella atrilutea sp. nov.}

Loktanella atrilutea (at.ri.lu'te.a. L. adj. ater -tra -trum dark; L. adj. luteus - $a$-um orange; N.L. fem. adj. atrilutea dark orange).

Cells are Gram-negative, aerobic and rod-shaped, approximately $1.8-2.0 \times 0.5-1.0 \mu \mathrm{m}$. Motile by means of a subpolar flagellum. Colonies on MA plates are round and beige-coloured; older colonies are dark orange. Cytochrome oxidase- and catalase-positive. Optimal growth temperature is $25-30{ }^{\circ} \mathrm{C}$; able to grow at $8{ }^{\circ} \mathrm{C}$, but not at $37{ }^{\circ} \mathrm{C}$. The $\mathrm{pH}$ range for growth is $6.0-8.0$. Growth occurs at $\mathrm{NaCl}$ concentrations of $0-8 \%$ on $\mathrm{R} 2 \mathrm{~A}$ agar, but no growth is observed on NA or TSA. Positive for alkaline phosphatase, esterase (C4), esterase lipase (C8), leucine arylamidase, acid phosphatase, naphthol-AS-BIphosphohydrolase, $\alpha$-galactosidase, $\alpha$-glucosidase and $\beta$ glucuronidase. Positive for degradation of Tweens (20, 40, 60 and 80). Acid is produced from arabinose, cellobiose, fructose, galactose, glucose, lactose, maltose, mannose, raffinose, rhamnose, sorbitol, sucrose and xylose. Does not decompose alginate, citrate, DNA, starch, tyrosine or urea. Does not reduce nitrate. Does not produce acetoin, $\mathrm{H}_{2} \mathrm{~S}$ or

Table 2. Fatty acid profiles of strain $I G 8^{\top}$, L. salsilacus $L M G$ $21507^{\top}$ and L. fryxellensis LMG $22007^{\top}$

Strains: 1, L. atrilutea sp. nov. $\mathrm{IG}^{\mathrm{T}} ; 2$, L. salsilacus $\mathrm{LMG} 21507^{\mathrm{T}} ; 3, \mathrm{~L}$. fryxellensis LMG $22007^{\mathrm{T}}$. Values are percentages $(\mathrm{w} / \mathrm{w})$ of total fatty acids.,$-<1 \%$ total fatty acid or not detected.

\begin{tabular}{|lccc|}
\hline Fatty acid & $\mathbf{1}$ & $\mathbf{2}$ & $\mathbf{3}$ \\
\hline $10: 03-\mathrm{OH}$ & 1.5 & 1.3 & 1.3 \\
$16: 0$ & 9.5 & 3.2 & 4.0 \\
$18: 1 \omega 7 c$ & 74.4 & 85.5 & 86.3 \\
$18: 0$ & 2.2 & 1.5 & 2.9 \\
$11-$ Methyl $18: 1 \omega 7 c$ & 6.3 & - & - \\
Summed feature $2^{*}$ & 3.8 & - & 1.5 \\
Summed feature $3^{\star}$ & - & 2.7 & - \\
Summed feature $7^{*}$ & 1.0 & 2.1 & 3.2 \\
\hline
\end{tabular}

* Summed features represent the following combinations of fatty acids: 2, 12:0 aldehyde, 16:1 iso I, 14:0 3-OH and/or unknown $10.928 ; 3,16: 1 \omega 7 c$ and/or $15: 0$ iso $2-\mathrm{OH} ; 7,19: 1 \omega 6 c, 19: 0$ cyclo $\omega 10 c$ and/or unknown 18.846 . indole. Negative for arginine dihydrolase, lysine decarboxylase, ornithine decarboxylase, tryptophan deaminase, lipase (C4), valine arylamidase, cystine arylamidase, trypsin, chymotrypsin, $\beta$-galactosidase, $\beta$-glucosidase, $N$-acetyl $-\beta$ glucosamidase, $\alpha$-mannosidase and $\alpha$-fucosidase. Does not produce acid from dulcitol, glycerol, inositol, mannitol or trehalose. The major fatty acid is $18: 1 \omega 7 c$. The DNA $\mathrm{G}+\mathrm{C}$ content of the type strain is $66.3 \mathrm{~mol} \%$.

The type strain, IG8 ${ }^{\mathrm{T}}\left(=\mathrm{IAM} 15450^{\mathrm{T}}=\mathrm{NCIMB} 14280^{\mathrm{T}}\right)$, was isolated from seawater off the Sanriku coast, Japan.

\section{Acknowledgements}

We thank K. Uematsu (Japan Agency for Marine-Earth Science \& Technology, JAMSTEC) for operating the electron microscopic system.

\section{References}

Altschul, S. F., Gish, W., Miller, W., Myers, E. W. \& Lipman, D. J. (1990). Basic local alignment search tool. J Mol Biol 215, 403-410.

Barrow, G. I. \& Feltham, R. K. A. (1993). Cowan and Steel's Manual for the Identification of Medical Bacteria, 3rd edn. Cambridge: Cambridge University Press.

Ezaki, T., Hashimoto, Y. \& Yabuuchi, E. (1989). Fluorometric deoxyribonucleic acid-deoxyribonucleic acid hybridization in microdilution wells as an alternative to membrane filter hybridization in which radioisotopes are used to determine genetic relatedness among bacterial strains. Int J Syst Bacteriol 39, 224-229.

Hosoya, S., Arunpairojana, V., Suwannachart, C., Kanjana-Opas, A. \& Yokota, A. (2006). Aureispira marina gen. nov., sp. nov., a gliding, arachidonic acid-containing bacterium isolated from the southern coastline of Thailand. Int J Syst Evol Microbiol 56, 2931-2935.

Ivanova, E. P., Zhukova, N. V., Lysenko, A. M., Gorshkova, N. M., Sergeev, A. F., Mikhailov, V. V. \& Bowman, J. P. (2005). Loktanella agnita sp. nov., and Loktanella rosea sp. nov., from the north-west Pacific Ocean. Int J Syst Evol Microbiol 55, 2203-2207.

Kimura, M. (1980). A simple method for estimating evolutionary rates of base substitutions through comparative studies of nucleotide sequences. J Mol Evol 16, 111-120.

Lau, S. C. K., Tsoi, M. M. Y., Li, X., Plakhotnikova, I., Wu, M., Wong, P.-K. \& Quin, P.-Y. (2004). Loktanella hongkongensis sp. nov., a novel member of the $\alpha$-Proteobacteria originating from marine biofilms in Hong Kong waters. Int J Syst Evol Microbiol 54, 2281-2284.

Mesbah, M., Premachandran, U. \& Whitman, W. B. (1989). Precise measurement of the $\mathrm{G}+\mathrm{C}$ content of deoxyribonucleic acid by highperformance liquid chromatography. Int J Syst Bacteriol 39, 159-167.

Saito, H. \& Miura, K. (1963). Preparation of transforming deoxyribonucleic acid by phenol treatment. Biochim Biophys Acta 72, 619-629.

Saitou, N. \& Nei, M. (1987). The neighbor-joining method: a new method for reconstructing phylogenetic trees. Mol Biol Evol 4, 406-425.

Smibert, R. M. \& Krieg, N. R. (1994). Phenotypic characterization. In Manual of Method for General and Molecular Bacteriology, pp. 607654. Edited by P. Gerhardt, R. G. E. Murray, W. A. Wood \& N. R. Krieg. Washington, DC: American Society for Microbiology.

Thompson, J. D., Gibson, T. J., Plewniak, F., Jeanmougin, F. \& Higgins, D. G. (1997). The CLUSTAL_X windows interface: flexible strategies for multiple sequence alignment aided by quality analysis tools. Nucleic Acids Res 25, 4876-4882. 
Van Trappen, S., Mergaert, J. \& Swings, J. (2004). Loktanella salsilacus gen. nov., sp. nov., Loktanella fryxellensis sp. nov. and Loktanella vestfoldensis sp. nov., new members of the Rhodobacter group, isolated from microbial mats in Antarctic lakes. Int J Syst Evol Microbiol 54, 1263-1269.

Wayne, L. G., Brenner, D. J., Colwell, R. R., Grimont, P. A. D., Kandler, O., Krichevsky, M. I., Moore, L. H., Moore, W. E. C., Murray, R. G. E. \& other authors (1987). International Committee on Systematic Bacteriology. Report of the ad hoc committee on reconciliation of approaches to bacterial systematics. Int J Syst Bacteriol 37, 463-464.

Weon, H.-Y., Kim, B.-Y., Yoo, S.-H., Kim, J.-S., Kwon, S.-W., Go, S.-J. \& Stackebrandt, E. (2006). Loktanella koreensis sp. nov., isolated from sea sand in Korea. Int J Syst Evol Microbiol 56, 2199-2202. 